Chimalpahin's Conquest 


\section{SERIES CHIMALPAHIN}

Susan Schroeder, General Editor 


\title{
Chimalpahin's Conquest
}

\author{
A Nahua Historian's Rewriting of
}

Francisco López de Gómara's La conquista de México

EDITED AND TRANSLATED BY

Susan Schroeder,

Anne J. Cruz, Cristián Roa-de-la-Carrera, and David E. Tavárez 
Stanford University Press

Stanford, California

(C) 2010 by the Board of Trustees of the Leland Stanford Junior University.

All rights reserved.

This book has been published with the assistance of the Dean's Office of the School of Liberal Arts, Tulane University, and the Program for Cultural Cooperation between Spain's Ministry of Culture and United States Universities.

No part of this book may be reproduced or transmitted in any form or by any means, electronic or mechanical, including photocopying and recording, or in any information storage or retrieval system without the prior written permission of Stanford University Press.

Printed in the United States of America on acid-free, archival-quality paper

Library of Congress Cataloging-in-Publication Data

Chimalpahin Cuauhtlehuanitzin, Domingo Francisco de San Antón Muñón, I 579-I 660.

[Conquista de México. English]

Chimalpahin's conquest : a Nahua historian's rewriting of Francisco López de Gómara's La conquista de México / edited and translated by Susan Schroeder ... [et al.].

p. cm. -- (Series Chimalpahin)

Includes bibliographical references and index.

Translated from the Spanish manuscript.

ISBN 978-0-8047-6948-8 (cloth : alk. paper)

I. Mexico--History--Conquest, I 5 I9-I 540--Early works to I800. 2. Cortés, Hernán, I485-I 547. 3. Nahuas--Social life and customs--Early works to I 800. 4. López de Gómara, Francisco, I 5 I I-I 564 . Crónica de la Nueva España. 5.

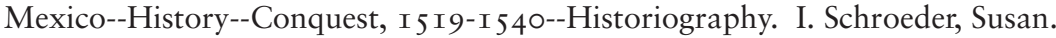
II. López de Gómara, Francisco, I 5 I I-I 564 . Crónica de la Nueva España. III. Title. IV. Series: Series Chimalpahin. FI230.C38 5 C47 I 320 I0 972 '.02--dc22

$$
2010001469
$$

Typeset by Bruce Lundquist in Io/I2 Sabon 